Albert Christian Paulsen (f.1935) er uddannet som lærer og cand.pæd. i fysik. Han er lektor emeritus fra Roskilde Universitet, hvor han i mere end 25 år har undervist i fysik og fagdidaktik og været vejleder for speciale- og ph.d.studerende i natur-

fagsdidaktik. Han har deltaget i læseplansarbejde og i evaluering af fysikundervisningen i det almene danske gymnasium. I sin forskning har han i de senere år især interesseret sig for naturfagenes bidrag til almendannelse og for elevers læring $\mathrm{i}$ naturfagene i relation til det praktiske arbejde. Internationalt har han deltaget i flere europæiske forskningsprojekter st $\varnothing \mathrm{t}-$ tet af EU og senest været deltager i det nordiske NORDLAB-projekt. Han har i årenes l $\emptyset \mathrm{b}$ forfattet, bidraget til og redigeret undervisningsmaterialer i naturfag og bøger om naturfagsdidaktik.

\title{
Naturfag i skolen i et kritisk demokratisk dannelsesperspektiv
}

\section{DET KRITISKE DEMOKRATISKE DANNELSESPERSPEKTIV}

I sin bog: "Naturfag som allmenndannelse - en kritisk fagdidaktik" har Svein Sjøberg (1998 s.37) denne vision om skolen og dens naturfagsundervisning: "-- skolen skal bidra til at elevene utvikler sig til individer som er $i$ stand til å delta på en selvstendig, reflektert og kritisk måte $i$ vort demokratiske samfunn". En sådan vision kommer også til udtryk hos den tyske dannelsesteoretiker Wolfgang Klafki (2001, s. 68, her forkortet af forfatteren). Han ser dannelse som en sammenhæng mellem tre grundlæggende evner:

1. Evnen til selvbestemmelse, dvs. selv at bestemme over egne levevilkår og egne meninger.

2. Evnen til medbestemmelse, dvs. at have krav på, mulighed for og ansvar for at udforme fælles kulturelle, samfundsmæssige og politiske forhold.

3. Evnen til solidaritet, dvs. at selv- og medbestemmelse kun kan retfærdiggøres, hvis evnen til selv- og medbestemmelse ikke blot anerkendes, men forbindes med solidaritet med de mennesker, som er afskåret fra at udfolde disse evner på grund af samfundsmæssige forhold, politiske begrænsninger og undertrykkelse eller underprivilegering.

Et dannelsesbegreb, som det fremstilles her, er således dybt forankret i visioner om et demokratisk og solidarisk samfund. Svein Sjøberg peger imidlertid også på, at naturfagene ikke altid har hørt til de almendannende fag. Netop dannelsesbegrebets historie har ifølge Klafki (2001, s.59) betydning for, hvilke opfattelser der også i dag gør sig gældende i den pædagogiske diskurs og dermed også for, hvordan og med hvad naturfagene kan bidrage til den almene dannelse i et kritisk demokratisk perspektiv. Svein Sjøberg (1998, s.37) skriver videre: "Det kan voere verdt at peke på at dannelse ikke er et produkt man kan erverve sig". Naturvidenskaberne har i skolemæssig sammenhæng i høj grad været opfattet som et produkt, som det kan være nyttigt at erhverve sig for den enkeltes og for samfundsøkonomiens skyld. Det vil fremgå af det følgende, at et sådant rationale næppe rummer noget større kritisk demokratisk dannelsesperspektiv. Skal de demokratiske visioner forenes med et historisk betinget traditionelt syn på naturfagene i den samme læreplan, da bliver situationen problem-, ja konfliktfyldt. Det vil enhver, der har deltaget i udvalgsarbejde om læreplaner, kunne bevidne. Den endelige læreplan er derfor ifølge Sjøberg (1998, s.181): "...ofte ideologiske dokumenter som glatter over at det finnes motscetninger og interessekonflikter. Loereplaner kan ofte peke i flere retninger samtidig slik at alle kan voere fornøyed. Men i praksis kan konflikten voere reell. Da er den likevel mer privatisert og overlatt til den enkelte loerer". Sådanne dannelsesmæssige modsætninger med politiske overtoner fremtrådte klart i løbet af det danske læreplansarbejde 
i begyndelsen af 1970'erne, hvor et ny regering ikke fandt formuleringer om at udvikle evnen til kritisk stillingtagen som baggrund for at handle i et demokratisk samfund for politiske korrekt. Dannelsespolitiske diskussioner var på det tidspunkt stærkt påvirket af frigørelsespædagogikken repræsenteret f.eks. ved Oscar Negt (1977) og et kritisk demokratisk dannelsesperspektiv blev anset for politisk venstreorienteret og indoktrinerende.

I 1960'erne og 70'erne blev undervisningen i naturfagene påvirket af angloamerikanske ideer, og med baggrund i efterkrigstidens behov for især teknisk uddannet arbejdskraft ændredes uddannelserne, så de sigtede på et begrebs - og metodemæssigt produkt, som var i overensstemmelse med grundlæggende naturvidenskabelige begreber og metode. Fortalerne for denne videnskabscentrerede læreplanstænkning hævdede, at der i beherskelse af selve den naturvidenskabelige viden og metode også lå et alment dannelsesperspektiv. Således argumenterede Phenix (1962 og 1964) for, at et vidensprodukt, som var skabt i samfundets forskningsinstitutioner måtte danne grundlaget for den kulturelle og sociale dannelse. For at skabe dette produkt blev undervisningspraksis præget af behavioristisk undervisningsteknik, hvor de instrumentelle færdigheder var mere fremtrædende end de reflektoriske. En instrumentel opfattelse af den naturvidenskabelige arbejdsmetode blev således anset for at være et kritisk rationelt instrument til at håndtere ikke blot naturvidenskabelige men også alment menneskelige og samfundsmæssige problemstillinger. Læreplanen og undervisningspraksis afspejlede imidlertid snarere et tilpasningsperspektiv. Således var holdningen til den teknologiske udvikling ifølge Paulsen (1980 og 1987) mere præget af teknologioptimisme og accept af en uafvendelig udvikling end af kritisk stillingtagen. Undervisningsaktiviteter, der rummede naturvidenskabelige forhold i en samfundsmæssig kontekst, forekom kun som ekstracurriculare aktiviteter. Det sidste kan man f.eks. med en vis ret sige om den danske miljøundervisning, hvis kritiske, handlingsorienterede og politiske dannelsesperspektiv er behandlet af Jensen og Schnack (1994) på baggrund af 70'ernes kritiske emancipatoriske pædagogik. 1970'ernes kritiske pædagogik vendte sig imod tilpasningspædagogikken, således hævdede Bent Nielsen (1973, s.40-41), at der i dannelsesbegrebet "...udover indsigt $i$ et vidensområde også (ligger), at man har etableret et kriterium for anvendelse af denne viden, at man har accepteret et ansvar for, hvordan og hvornår og til hvad man vil anvende denne viden". Heri ligger der et kritisk og reflektorisk dannelseselement, som går ud over den rent vidensformidlende undervisning. "Demokrati forutsetter kritisk fornuft og rasjonalitet" fremhæver Svein Sjøberg (1994 s.37), hvor nøgleordet er kritisk. Det drejer sig da om en politisk dannelse $i$ et demokratisk perspektiv, der som Karsten Schnack (1994, s. 96) skriver, ikke "handler .. om at blive socialiseret på plads $i$ systemet, men at blive dannet som politisk toenkende deltager (i modscetning til tilskuer) $i$ demokratiet ...... Demokrati krcever politisk dannede borgere, og politisering er det bedste vaern mod indoktrinering". Ved politisering skal her forstås refleksioner over samfundets indretning med henblik på ændringer ved at udnytte de handlemuligheder, som individet har i et demokratisk samfund. Allerede i 1915 skriver John Dewey (1966, p.88) om at alle samfundsborgere må uddannes til personligt initiativ, for at de få ikke skal udbytte de mange.

\section{DE GODE INTENTIONER?}

I naturfagene og især i fysik og kemi har der været undervist udfra et uddannelsesmæssigt nytteperspektiv med henblik på elevernes mulige fremtidig karriere indenfor teknik og naturvidenskab, og fagene har været fremstillet som objektive rationelle videnskaber hævet over ideologier og andre affektive forhold. Erik Knain (1999 s.229) har kaldt det et "opplysningsperspektiv" med henvisning til oplysningstiden. Langt hovedparten af dette traditionelle indhold i den naturfaglige undervisning er i læreplanen bevaret som et abstrakt begrebsmæssigt historisk betinget indhold, som også hævdet af Edgar Jenkins (1999). Pointen med at kaste blikket bagud i tiden er at give en baggrund for, at de nuværende læreplaners formålsformuleringer repræsenterer kompromiser, hvoraf et af de væsentlige dækker over den kontroversielle konflikt mellem et nytte- og oplysningsperspektiv eller mere politisk udtrykt et accepterende tilpasningsperspektiv og et kritisk demokratisk perspektiv. Hvad der nemlig blev anset for kontroversielt og politisk venstredrejet i 
partipolitisk forstand i 1970'erne, står nu mere eller mindre i skolernes formålsformuleringer ikke mindst i de skandinaviske lande. Det kan således læses ind i fagformålene for den danske folkeskoles "Formål og centrale færdighedsområder" (Undervisningsminesteriet 1994) for fysik/kemi: "Undervisningen skal bidrage til elevernes grundlag for at få indflydelse på og tage medansvar for brugen af naturressourcer og teknik både lokalt og globalt" og for biologi: "Elevernes ansvarlighed overfor natur og miljø skal videreudvikles, og undervisningen skal bidrage til at skabe grundlag for stillingtagen og handlen i forhold til menneskets samspil med naturen". Disse formål står imidlertid (bevidst?) efter begrebs- og processuelle formål og har i de følgende bestemmelser for undervisningen og i vejledningerne en tilbagetrukken placering. Således har også det kritiske demokratiske element i de norske læreplaner "Læreplanverket for den 10-årige grunnskolen" (KUF 1996) vedrørende naturfag et meget lille omfang i forhold til det begrebsmæssige indhold.

Udviklingen af et kritisk demokratisk beredskab når således ikke ret langt ud over formålsplanet i de fleste læreplaner. Selvom læreplaner fornys med efterhånden få års mellemrum, så er der ikke tale om egentlig pædagogisk nytænkning. Det er snarere tilføjelser til et traditionsbestemt indhold, som netop afspejler en interessekonflikt mellem naturvidenskabelige begreber og metoder som et mål i sig selv overfor naturvidenskabens kulturelle og samfundsmæssige perspektiver. Flere forhold har siden 1980'erne betinget, at et alment dannelsesperspektiv herunder det demokratiske dannelsesperspektiv har fået indpas i læreplanerne om end i det væsentlige kun på et formelt og retorisk plan.

For det første kan man nok ikke frakende påvirkningen fra udlandet som f.eks. STS bevægelsen (Sience, Technology and Society) især i Storbritannien, USA og Canada en vis indflydelse på den pædagogiske debat. Erik Jørgensen (1999) har rapporteret om sådanne projekter i nyere tid. STS bevægelsen skabte en fornyelse, men som Jenkins (1992) påpeger, ikke som en grundlæggende pædagogisk ændring af læreplaner og undervisningspraksis i naturfagene men som tilføjelser. Ligeledes har begreber som Scientific literacy, Science for all, Science for citizenship og lignende haft stor signalværdi. Begrebet Scientific literacy blev allerede skabt i 1960'ernes videnskabscentrerede ånd. Dengang som nu havde initiativerne baggrund i en voksende bekymring vedrørende den almindelige borgers manglende oplysthed om samfundsmæssige forhold, der rummede naturvidenskabelige videnselementer. Således argumenterede Karplus og Thiers (1966) for nødvendigheden af, at borgeren beherskede de væsentligste naturvidenskabelige begreber og den naturvidenskabelige arbejdsmetode som et rationelt redskab i det moderne samfund. Lignende tanker fremgår af Fenshams (2000) redegørelse om Science for all og en rapport af Sjøberg og Kallerud (1997) ligesom det spiller en rolle i OECD's PISA-projekt, se f.eks. Harlens (1999) redegørelse for tankerne i projektet.

For det andet har den uddannelsespolitiske udvikling i de skandinaviske samfund medført, at en elitær undervisning for de få ikke må hindre en almendannende undervisning for de mange.

For det tredje er der sket en ændring i opfattelsen af naturvidenskaberne, fra at de giver et sandt billede af naturen til at de repræsenterer den mest levedygtige men foreløbige beskrivelse konstrueret af mennesker. Derudover er de, som fremhævet af Jenkins (2000), gået fra at være blevet anset som rene og objektive videnskaber hævet over ideologi og samfundsmæssigt engagement til at være videnskaber, som udover nysgerrigt og spekulativt udforsker naturen også er involveret $\mathrm{i}$ industriel, militære og kommercielle interesser.

Endelig for det fjerde har et tungtvejende argument for ændringer ikke mindst været en formodning om, at de socio-politiske og -kulturelle perspektiver kan medvirke til, at ungdommen bliver motiveret til at engagere sig i en naturvidenskabelig uddannelse. Noget provokerende sagt, er det måske denne sidste gustne fagpolitiske betragtning snarere end en egentlig revurdering af skoleuddannelsen, som er en medvirkende årsag til kompromiserne og til karakteren af tilføjelser. I Danmark blev der sidst i 1980`erne indføjet meget væsentlige historisk-filosofiske og teknologisk- 
samfundsmæssige perspektiver i gymnasiets læreplan for fysik. Se f.eks. nogle af tankerne i Nielsen og Thomsen (1990). Disse perspektiver er imidlertid senere i Gymnasiebekendtgørelsen (1999) blevet betydeligt nedtonede. De kom aldrig til udfoldelse i undervisningen i overensstemmelse med intentionerne og har ikke medført større ændringer i undervisningspraksis. Såvel de danske lærebøger som lærerne synes at fastholde et traditionelt indhold med henvisning til læreplanens øvrige begrebs- og metodemæssige indhold. Dette fremgår også af en evaluering af fysikundervisningen i det danske almene gymnasium "Fysik i skole - skolen i fysik" (2001). Her henviser lærerne i gymnasiet til eksamenskrav, som ikke omfatter perspektiverne og til de af undervisningsministeriet beskikkede censorer, som efter lærernes opfattelse fastholder en traditionel faglig linie ved den mundtlige eksamen. Der lægges forholdsvis meget mere vægt på begrebsmæssig præcision end på de ofte tværfaglige og såkaldte "bløde" perspektiver. Disse forbehold mod ændringer, som bl.a. Fensham (2000 s.161) beskriver, kan imidlertid ikke blot begrundes med banal konservatisme i institutionerne, bagstræb og frustrationer, som nye læreplaner uundgåeligt skaber. Her er der efter min mening tale om den reelle konflikt, der bliver privatiseret og overladt til den enkelte lærer, som nævnt af Svein Sjøberg. Ikke overraskende viser konflikten sig i valg af det faglige indhold og i undervisningspraksis ved at perspektiverne ignoreres. Jeg vil hævde, at den skjulte konflikt indirekte kommer til udtryk i ovennævnte rapport, som en frustration blandt lærerne og en desorientering om skolefagets rationale blandt eleverne.

Erik Knain (1999, s.229) beskriver konflikten som et spændingsforhold mellem et "opplysningsperspektiv" og "kritisk perspektiv". I oplysningsperspektivet danner læreplanens indhold af naturvidenskabelige begreber, processer og metoder grundlaget for undervisningspraksis. I dette faglige univers af kendt viden skal eleverne lære at udtrykke sig præcist om naturen, argumentere rationelt og belægge argumenter med observationer og eksperimentelle data. Der er tale om begreber og metoder, som intenderer at kunne anvendes og tilpasses en vilkårlig kontekst, og hvor argumentationen holder sig indenfor de rationelle rammer af kendt og afsluttet naturvidenskabelig viden. Heri ligger oplysningsperspektivets almene dannelse. Det anses for alt nok. Der er ikke rum for et kontekstuelt socio-politisk endsige kritisk indhold. Det anses heller ikke for nødvendigt, idet undervisningen antages at levere de rationelle redskaber til også at forholde sig til socio-politiske forhold. Paradoksalt nok er det, som Eger (1989) hævder, en accepteret opfattelse, at naturvidenskabelig forskning især i nyere tid har vidtrækkende etiske og samfundsmæssige konsekvenser, som borgerne må og bør tage stilling til. Ligeledes er de ovenfor nævnte erkendelsesmæssige opfattelser af naturvidenskab som en særdeles menneskelig socialt betinget stræben almindelig accepteret. Det kommer imidlertid ikke til udtryk som en integreret del af undervisningen. Den forekommer i læreplanerne og i indledningen til visse lærebøger, men forbliver rent retorisk i undervisningspraksis. Pointen er her jo, at det netop er de etablerede teorier, som danner undervisningens indhold. Nyere naturvidenskabelige forskningsresultater og anvendelse af naturvidenskab bliver yderst sjælden inddraget. I modsætning til oplysningsperspektivets indhold af kendt og afsluttet viden vil den naturfaglige undervisning i en socio-politisk problemstilling ofte rumme uafsluttet viden, hvor eksperterne ikke er enige om anvendelsen og konsekvenserne. Dertil kommer at viden i socio-politiske sammenhænge og i dagligdagen er kontekstafhoengig. David Layton (1991 s.69) beskriver, hvordan den traditionelle undervisnings stræben efter generalitet og kontekstuafhængig viden kræver reorganisering i kontekstafhængige sammenhænge, for at kunne anvendes i praktiske hverdagssituationer, hvor også værdispørgsmål, troværdighed og tillid kommer til at spille en væsentlig rolle for den enkeltes stillingtagen.

\section{DE FÅ OVERFOR DE MANGE}

Flertallet af eleverne - de mange - vil ikke forfølge en naturvidenskabelig uddannelse. Omfattende forskning om elevers hverdagsbegreber synes at vise, at de mange aldrig kommer til at beherske de naturvidenskabelige begreber og et naturvidenskabeligt sprog, dvs. kunne deltage i en naturvidenskabelig diskurs. Ligeledes synes forskning ifølge Layton (1991) og Edgar Jenkins (1994 s.603) at vise, at den almindelige borger ikke kan anvende sin skoleviden, med mindre det bliver 
sat i en kontekstuel sammenhæng. Spørgsmålet er da, om det tvedelte formål, naturvidenskab for sin egen skyld og naturvidenskab for at udvikle kulturel forståelse og socio-politiske kompetencer er forenelige i den samme undervisningspraksis. En ikke ualmindelig historisk betinget poedagogisk hverdagsopfattelse, som skjuler konflikten er jo, at disciplinens teorier, begreber og metoder opfattes som kognitive redskaber eller en mental vaerktøjskasse til at bemestre dagligdagen og dens socio-politiske forhold. Sådan er det imidlertid ikke som Jonathan Osborne (2000 s.226) også påpeger. Også Edgar Jenkins (1994 s.609) mener, at et demokratisk handleberedskab vil kræve et rationale, som er fundamentalt forskellig fra en traditionel læreplan. De to dele af formålene er uforenelige, idet de tilhører hver sin diskurs nemlig en naturvidenskabelig diskurs og en kulturel, socio-politisk diskurs. Kan det tænkes, at den konventionelle opfattelse af naturfagenes indhold, som er adækvat i den ene diskurs ikke er det i den anden? Måske bidrager den traditionelle elektricitetslære slet ikke til hverken forklaringer eller praktiske anvendelser i dagligdagen? En række undersøgelser af den almindelige borgers manglende indsigt i forhold i samfundet med et naturvidenskabeligt indhold har i de sidste år bekymret mange indenfor uddannelsessektoren. En sådan kognitiv deficit i befolkningen, som Layton og andre (1993) kalder det, er i sig selv ikke noget nyt. Imidlertid hævder Ziman (1991) at afstanden mellem borgerens indsigt i disse forhold og naturvidenskabens faktiske betydning for samfundsudviklingen vokser foruroligende. Skoleuddannelse synes at have lille eller ingen indflydelse. Svein Sjøberg (1997) og Edgar Jenkins (1997) refererer undersøgelser, som viser, at borgere i situationer, hvor de konkret har brug for naturvidenskabelig viden, ikke anvender deres skoleviden, men udvikler kontekstuel viden i situationen. Måske stiller den institutionaliserede naturfagsundervisning med sin stræben efter et kontekstuafhængig indhold sig $i$ vejen for en undervisning, der forfølger socio-politiske mål? Brian Wynne (1991 s.121) perspektiverer den kognitive deficit i et større politisk perspektiv, idet han mener, at et forarmet demokrati intensiverer naturvidenskabens hegemoniske rolle i samfundet. Dette fremhæver yderligere behovet for at indrette undervisningen sådan, at naturfagene bidrager til et kritisk demokratisk beredskab, hvor ordet beredskab antyder, at undervisningen er fremtidsindrettet. Dermed unddrager den sig også en konventionel evaluering af et undervisningsindhold, da resultatet først viser sig i fremtidige handlinger. Men det er vel det, dannelse drejer sig om?

Konsekvensen af det uforenelige i læreplanernes formål kunne da være, som Klaus Emmeche (1999) antyder, at udskille de få som tilstræber en naturvidenskabelig uddannelse fra de mange som bare skal være " $i$ stand til å delta på en selvstendig, reflektert og kritisk måte $i$ vort demokratiske samfunn". Denne konsekvens søger nogle nyere læreplans- og undervisningsinitiativer at drage mere konkret, således "Beyond 2000" initiativet i England. Rapporten, som er skrevet og redigeret af Robin Millar og Jonathan Osborne (1998), opstiller en række indholds og procesmål om at skabe viden, interesse, selvtillid, selvstændig stillingtagen og personlig myndighed i samfundsforhold med et naturvidenskabeligt indhold. Et Kursus: "Science for Public Understanding", (AQA 2001/2) henvender sig til de 16-17 årige og rummer størstedelen af målene. Andre initiativer er omtalt i OECD publikationen "Changing the Subject" (Black og Atkin 1996). Et særligt etisk aspekt i handlingsperspektivet har det britiske "Science, Ethics and Education Project" (Fullick og Ratcliffe 1996). Disse initiativerne bygger alle snarere på en kontekstafhængig diskurs i socio-kulturel sammenhæng end på en traditionel kontekstuafhængig naturfaglig diskurs og i det følgende vil der blive set nærmere på forholdet mellem de to diskurser.

\section{TO DISKURSER}

Mens den viden som introduceres i ovenstående initiativer er kontekstafhængig og begrænset, så insisteres der i den pædagogiske debat ofte på en meget omfattende naturvidenskabelig viden, som en forudsætning for at opnå intellektuel uafhængighed, selvstændig stillingtagen og personlig myndighed. Men har den naturfaglige undervisning som mål, at eleven skal se eksperten kritisk over skulderen med en eksperts viden? Det drejer sig måske snarere om en viden om naturvidenskab og til de måder den manifesterer sig på i samfundet, som Mogens Niss og Jens Højgaard Jensen (1984) hævder. En person kan måske nok ikke foretage en faglig vurdering af naturvidenskabe- 
lige resultater. Men derfor kan personen godt have opfattelser af naturvidenskabelige resultater så som, at ikke alt er troværdigt, at det kan være styret af økonomiske og/eller politiske interesser, at der indenfor det naturvidenskabelige forskningsfællesskab altid er debat om resultaterne, at naturvidenskabelige resultater altid rummer forenklinger, approksimationer og kompromiser. Sådanne mål kan næppe tilgodeses ved en pensumliste, men som Kolstø (1997) skriver, må de praktiseres. Stephen Norris (1997) har kaldt dem for transcendentale ${ }^{1}$ mål, som skaber det Stephen Norris kalder epistemisk distance. Derved forstår han en position imellem den totale tiltro til og den totale afvisning af naturvidenskabelige resultater og deres anvendelse. Epistemisk distance er således et væsentligt mål for etablering et kritisk demokratisk beredskab.

Et tilsvarende synspunkt refererer også Aadu Ott (2000, p.96), idet han citerer Säljös socio-kulturelle opfattelse af, at det komplekse samfunds teknologiske side må forstås som meningsdomæner af forskellige situerede forklaringsmodeller og tænkemåder. Dette synspunkt skal imidlertid sammentænkes med, at der findes veletablerede og afprøvede naturvidenskabelige teorier og metoder, som ikke uden videre kan problematiseres, og som må anvendes situeret for at forholde sig kritisk til samfundsforhold. Aadu Ott leverer således eksemplet, idet han refererer Säljö for at energiforbrug er et bedre og mere direkte (brutalt!) begreb til at beskrive de samfundsmæssige konsekvenser af energiomsætningen end princippet om energibevarelse. Begrebet energiforbrug kan imidlertid kun anvendes i mere banale dagligdags sammenhænge, hvilket da er udmærket. Det er imidlertid uegnet til en kritisk socio-politisk vurdering af energiomsætningerne i samfundet, idet det her er begrebet nyttevirkning, som er af afgørende betydning, og det implicerer energibevarelse. Dette eksempel demonstrerer på sin vis ikke om naturvidenskabelige teorier og metoder er relevante i en socio-politisk diskurs. Spørgsmålet er snarere om de skal loeres kontekstafhængig i denne diskurs, eller om de skal læres isoleret, som generelle begreber uafhængige af kontekst i en disciplinær naturfaglig diskurs. Traditionelt tilstræbes energibevarelsen lært som et dekontekstualiseret begreb eventuelt demonstreret ved svingende penduler, sammentrykning af fjedre eller andre eksempler i et skolelaboratorium. Konsekvensen er ifølge Millar og Wynne (1988) og Layton og andre (1993), at begreberne kun ved en yderligere transformation og tilpasning til den komplekse virkelighed vil kunne anvendes i en socio-politisk diskurs. Det belyser igen den grundlæggende konflikt i læreplanerne, som det tvedelte formål rummer. Det må være indlysende, at det må komme eleverne til skade, når den konventionelle undervisning med en disciplincentreret naturfaglig diskurs på det retoriske plan hævder også at føre en socio-politisk og socio-kulturel diskurs. Det giver nemlig det indtryk, at den disciplincentrerede faglige diskurs med dens kontekstuafhængige begreber og rationalitet problemfrit lader sig transmittere til praktiske situationer og beslutningsprocesser i det virkelige liv. Dette synes indirekte at fremgå af den danske evaluering af fysikundervisningen i det almene gymnasium. Det fremgår imidlertid også, at en socio-politisk diskurs, der vil kunne tilgodese de transcendentale dannelsesmål om et kritisk demokratisk beredskab i allerhøjeste grad vil udfordre undervisningspraksis og den konventionelle opfattelser af undervisning, læring og evaluering. Konsekvensen af ovenstående betragtninger må nemlig være, at eleverne må udvikle et kritisk demokratisk beredskab i en undervisningspraksis, hvor de argumenterer, tager stilling og eventuelt handler på baggrund af egne forudsætninger, egne etiske værdier og politiske overbevisninger og på baggrund af den viden, de udvikler kontekstuelt i tilknytning til den socio-politiske diskurs. Men denne diskurs, der bygger på ligeværdighed og demokrati, forrykker den traditionelle magtbalance i undervisningen, som Kirsten Reisby (1994) gør opmærksom på. Pointen er, at den naturvidenskabelige diskurs, som læreren behersker og kan kontrollere, ikke længere er udgangspunkt for udviklingen af handlemulighederne i samfunds- og hverdagslivets praksis. Det er jo netop ikke så enkelt at anvende viden, som er tilegnet for sin egen skyld, i praktiske, politiske, samfundsmæssige eller personlige forhold. I en socio-politisk diskurs med et naturvidenskabeligt indhold er naturvidenskaben ifølge Layton og andre (1993 p.125) tilstede som en partner i diskursen. I de i reglen aktuelle situationer kan naturvidenskaben ofte ikke bidrage med sikker viden. ${ }^{1}$ Content-transcendent Goals. Transcendental: Som ligger ud over erfaringen; hvad der ikke er erfaret eller kan
erfares, men som er en forudsætning for, at vi kan have erfaring (Kant). 
Grundlaget for beslutninger må derfor også baseres på andre vidensområder såvel som etiske værdier, personlig troværdighed, samfundsnormer, egne meninger osv. I vurderingen af anvendelsen af naturvidenskabelig viden og af usikker viden kan alle principielt være lige respekterede deltagere i diskursen.

\section{EN MODSTILLING AF DIDAKTISKE METAFORER}

Skoleundervisningens tre væsentlige aspekter: det som skal læres, læringen og undervisningen sammenfattes ofte i metaforer, der på en gang reducerer kompleksiteten og karakteriserer de tre aspekter. Metaforen rummer således forestillinger om og opfattelser af den lærende og læring, underviseren og undervisning og om, hvilken viden, kunnen og erkendelse undervisningen drejer sig om. Fibæk Laursen (1998) diskuterer en række didaktiske metaforer. Velkendt er således den fra antikken kendte krukkemetafor, hvor eleverne er tomme krukker, som fyldes op med viden af læreren. En metafor som i nedsættende betydning også kaldes tankpasserpcedagogik, og som konstruktivismen gjorde op med. Især i det seneste årti har der været diskuteret didaktiske modeller af metaforisk karakter, som kan sættes i relation til de ovenfor omtalte modsætninger i læreplanerne. Således stiller er Erik Knain (1999, s.229) som omtalt af et oplysningsperspektiv overfor et kritisk socio-politisk perspektiv. Matematikdidaktikeren Anna Sfard (1998) modstiller to didaktiske metaforer, så de karakteriserer væsentlige forskelle i syn på viden og læring i relation til det, som har været diskuteret her. Hun stiller således en tilegnelsesmetafor overfor en deltagermetafor.

Tilegnelsesmetaforen rummer velkendte forestillinger om viden og læring, som det kommer til udtryk i en konventionel naturfagsundervisning. Viden kan her eksistere uafhængig af kontekst. Det kan skrives op som et pensum i en læreplan og erhverves af den enkelte elev ved passende pædagogiske indgreb fra lærerens side. Begreber og metoder kan tilegnes, så man har dem som kontekstuafhængige enheder og strukturer. Dette anses for en nødvendighed og en forudsætning for at begreber og metoder kan anvendes. Engang tilegnet vil disse strukturer kunne aktiveres og anvendes på ethvert system, med hvilket der er en begrebsmæssigt eller metodisk lighed eller fællesskab. Vendinger som at have begreber, at have foerdigheder, at eje viden er i overensstemmelse med tilegnelsesmetaforen. Mange af udtrykkene er en del af det fagdidaktiske sprog i læreplaner og på lærerværelser. Lærerrollen er præget af, at opgaven består i at levere kundskaber og foerdigheder til eleven. I et konstruktivistisk paradigme taler man om hverdagsbegreber, som eleverne har, og som i undervisningspraksis må konfronteres med naturvidenskabens begreber med henblik på at aendre elevernes begrebsopfattelser. De fleste prøver og eksaminer tager udgangspunkt i troen på, at man så at sige kan lukke et vindue op til den lærendes hoved og se, om et lærestof er tilegnet, for så må det findes derinde. Ofte forsøger læreren at forstå elevens mindre velartikulerede udtryk som tegn på, hvad eleven $i$ virkeligheden ved.

I deltagermetaforen opfattes læring, som en kontinuerlig udvikling af handlekompetencer ved at deltage i et praksisfællesskab. Mens man i tilegnelsesmetaforen fokuserer på internalisering af kontekstuafhængige strukturer og ændringer i en intern tilstand, så fokuserer man i deltagermetaforen på konteksten og på udvikling af eksterne handlemuligheder. Opfattelsen af læring skifter således fra ændringer i en intern tilstand til ændringer i eksterne handlemuligheder i en praksis og viden opfattes som indlejret i en praksis, som den ikke uden videre kan isoleres fra. Jytte Bang (1998) har kaldt det eksternaliseret loering, der ligesom Anna Sfards opfattelse af læring i deltagermetaforen er nært beslægtede med Lave and Wenger's (1991) begreber distributed knowledge, situated learning og legitimate, peripheral partecipation. Jean Lave (1988) udviklede sine ideer på baggrund af mester-lærlinge forholdet i et håndværksmæssigt praksisfællesskab. Dette apprenticeship-begreb anvender Brown, Collins and Duguid (1989) og siden Hennessy (1993) på forholdet mellem lærer og elev i skolen. I et sådant cognitive apprenticeship, mener de, kan der udvikles en praksis, som f.eks. en naturfaglig diskurs eller en kritisk socio-politisk diskurs, der rummer et naturvidenskabeligt element. Anna Sfard har modstillet de to metaforer skematisk i fig.1. 


\begin{tabular}{|l|l|l|}
\hline $\begin{array}{l}\text { Tilegnelsesmetafor } \\
\text { Acquisition metaphor }\end{array}$ & $\begin{array}{l}\text { Deltagermetafor } \\
\text { Participation metaphor }\end{array}$ \\
\hline $\begin{array}{l}\text { Personlig berigelse } \\
\text { Individual enrichment }\end{array}$ & $\begin{array}{l}\text { Læringsmål } \\
\text { Goal of learning }\end{array}$ & $\begin{array}{l}\text { Udvikling af et praksisfællesskap } \\
\text { Community building }\end{array}$ \\
\hline $\begin{array}{l}\text { Tilegnelse af noget } \\
\text { Acquisition of something }\end{array}$ & $\begin{array}{l}\text { Læring } \\
\text { Learning }\end{array}$ & $\begin{array}{l}\text { At blive deltager i en praksis } \\
\text { Becoming a participant }\end{array}$ \\
\hline $\begin{array}{l}\text { At modtage og (re)konstruere } \\
\text { viden } \\
\text { Recipient (consumer),(re-)con- } \\
\text { structor }\end{array}$ & $\begin{array}{l}\text { Elevrolle } \\
\text { Student }\end{array}$ & $\begin{array}{l}\text { At begynde at deltage i et praksisfælles- } \\
\text { skap } \\
\text { Peripheral participant, apprentice }\end{array}$ \\
\hline $\begin{array}{l}\text { Forsørger, tilrettelægger af } \\
\text { elevens læringsvilkår og for- } \\
\text { midler } \\
\text { Provider, facilitator, mediator }\end{array}$ & $\begin{array}{l}\text { Lærer } \\
\text { Teacher }\end{array}$ & $\begin{array}{l}\text { Ekspert, der deltager og vedligeholder } \\
\text { praksis og diskursen } \\
\text { Expert participant, preserver of practice/ } \\
\text { discourse }\end{array}$ \\
\hline $\begin{array}{l}\text { En ejendom, en vare, som kan } \\
\text { ejes } \\
\text { Property possession, commod- } \\
\text { ity (individual, public) }\end{array}$ & $\begin{array}{l}\text { Viden, begreper } \\
\text { og metoder } \\
\text { Knowledge, } \\
\text { concept }\end{array}$ & $\begin{array}{l}\text { Aspekter ved praksis, ved diskursen og } \\
\text { ved aktiviteterne } \\
\text { Aspect of practice/discourse/activity }\end{array}$ \\
\hline $\begin{array}{l}\text { At eje og have noget } \\
\text { Having, possessing }\end{array}$ & $\begin{array}{l}\text { Være vidende } \\
\text { Knowing }\end{array}$ & $\begin{array}{l}\text { Have et tilhørsforhold til en praksis, } \\
\text { kunne deltage I en diskurs og kommu- } \\
\text { nikere } \\
\text { Belonging, participating, communicating }\end{array}$ \\
\hline
\end{tabular}

Figur 1. Tilegnelsesmetaforen overfor deltagermetaforen ifølge Anna Sfard (1998) (overscettelse ved forfatteren).

\section{KONSEKVENSER FOR PADAGOGIKKEN?}

I det foregående er der argumenteret for, at naturfaglig undervisning i et kritisk demokratisk dannelsesperspektiv ikke blot er et spørgsmål om en tilføjelse til eksisterende læreplaner for, som Edgar Jenkins (1994 s.607) skriver: " Practical action or "capability",.., is strongly context dependent, not disciplinary, highly sensitive to the available knowledge base, and rich in values at every point". Edgar Jenkins (1997 s.609) ser sammen med David Layton (1991 s.69) de to rationaler så fundamentalt forskellige, at de er uforenelige i den samme læreplan. Andre som Aadu Ott (2000), Kolstø (2000) og Ødegaard (2001) tager udgangspunkt i en naturvidenskabelig diskurs for dernæst at restrukturere den naturvidenskabelige viden i konkrete socio-politiske kontekstuelle sammenhænge.

For undervisningspraksis finder jeg det helt afgørende at skelne mellem de to didaktiske rationaler, idet de sætter scenen for helt forskellige pædagogiske spilleregler såkaldte didaktiske kontrakter. Min pointe er, at det må være bevidst for lærer og elever og i videre forstand institutionen, hvilken didaktisk kontrakt der indgås. I den ene kontrakt er det den naturfaglige diskurs, som er fremherskende i undervisningen, hvor formålet er, at eleverne tilegner sig dekontekstualiserede naturvidenskabelige begreber og metoder i overensstemmelse med en tilegnelsesmetafor. De sociopolitiske perspektiver vil her holde sig indenfor rammerne af en naturvidenskabelig diskurs, som er meningsformidlende og i reglen styret og ledet af læreren. Råderummet er derfor på forhånd indsnævret med hensyn til mulige problemstillinger og elevdeltagelse. En kontrakt, der sigter på et kritisk demokratisk beredskab må tage udgangspunktet i forhold i den omgivende virkelighed f.eks. i konkrete samfundsforhold eller en aktuel debat. På den baggrund vil der i undervisningen etableres en socio-politisk diskurs i overensstemmelse med deltagermetaforen, hvor der må være 
adgang til endog ofte kompliceret naturvidenskabelig ekspertviden. Naturvidenskaben bidrager som en partner sammen med andre fagligheder, værdisynspunkter og personlige meninger. Her er lærer og elever ligevcerdige deltagere i en diskurs, som er meningsskabende. I begge diskurser anvendes imidlertid rationel argumentation og ræsonnementer, som Duschl and Ellenbogen (2001), Kolstø (2001), Osborne et.al. (2001) har beskæftiget sig indgående med. Forudsætningen for et kritisk demokratisk beredskab er imidlertid også en kritisk indstilling, som Harvey Siegel (1989, s 25) skriver: "..a critical thinker must not only be able to assess reasons properly,..., she must be disposed to do so as well". Udvikling af det kritiske demokratiske beredskab og epistemisk distance er nær forbundet med udvikling af identitet og personlig myndighed og dermed også kulturelt betinget og forankret.

\section{EN MULIG UNDERVISNINGSPRAKSIS?}

Det er min påstand, at deltagermetaforen som didaktisk model har nogle pædagogiske kvaliteter, som det vil være hensigtsmæssigt at omsætte til undervisningspraksis med henblik på at udvikle et kritisk demokratisk handleberedskab, men der savnes mere omfattende forskning på området, derfor kan dette kun være af tentativ karakter. Det drejer sig da her om en didaktisk kontrakt, hvor elever og lærere er bevidste om deres roller som deltagere i diskursen. Men også i en sådan kontrakt vil læreren sandsynligvis repræsentere en magtfaktor. Imidlertid har vi i de skandinaviske landes skoler en langt mere antiautoritær tradition i klasserumsdiskursen end i mange andre lande. Eleverne bliver i høj grad anerkendt som personer med selvstændige meninger, og de kan problematisere en lærers ytringer, som et anerkendt og - afhængig af læreren - endog tilstræbt led i læreprocessen. De praksiselementer, som kan give anledning til udviklingen af et kritisk demokratisk beredskab kunne da være:

- at eleverne får mulighed for at italesætte et virkelighedsnært, autentisk og gerne kontroversielt emne eller problem, som rummer et naturvidenskabeligt element,

- at eleverne har medindflydelse på valg af emner og problemer og deres bearbejdning,

- at disse emner og problemer erkendes og accepteres af eleverne,

- at eleverne har mulighed for at komme til orde i en tryg atmosfære,

- at der lægges vægt på argumentationer, vurderinger og handlemuligheder

I en diskussion af praksis er det væsentligt at fastholde, at scenariet er det offentlige rum, hvor naturvidenskabelig viden, sikker såvel som usikker, anvendes som en aktiv agent i en beslutningsprocessen, men hvor mange afgørelser baseres på værdier. Resultatet kan da være en stillingtagen eller en beslutning om en handling på det individuelle plan eller i et fællesskab.

\section{Klassedialog.}

Den traditionelle klassedialog i en naturvidenskabelig diskurs er i reglen den Lemke (1990) kalder den triadiske dialog, fordi den består af tre dele, læreren, der stiller spørgsmål, eleven, der besvarer og læreren, der evaluerer svaret. Den didaktiske kontrakt går ud på, at eleverne skal tilegne sig viden ved at svare på spørgsmål, som læreren kender svaret på. Dialogen kan udmærket også rumme meninger, men det vil da være meninger, som formidles, idet hensigten er, at alle ender med at acceptere dem. Sådanne læreprocesser i klasse- og gruppedialoger er i øvrigt udførlig beskrevet af Jytte Bang (2001) og Jens Dolin (2000) i forbindelse med ALF(At Lære Fysik)-projektet i Danmark.

Den meningsskabende klassedialog rummer usikker og uvis viden og måske uigennemtænkte meninger, fordomme og værdier, som skal prøves i en dialog. Deltagerne kan da til forskel fra den triadiske dialog udtrykke usikre formuleringer og manglende klarhed. Det kan blive risiko- og konfliktfyldte situationer, men også give mulighed for, at den enkelte deltager kan gå ud over sine tidligere opfattelser. Konsensus er kun en af de mulige udgange på en klassedialog, idet der ikke behøver at være kun én og samme sandhed for alle deltagere. Modsætninger kan blive bevaret $\mathrm{i}$ respekt for hinandens forskelle og for friheden og mangfoldigheden, men ikke uden at de har været 
genstand for argumentation og kritisk analyse. Sådanne dialoger kan være identitetsskabende og personlighedsudviklende og bidrager til at skabe den epistemiske distance og intellektuel selvstændighed, som Stephen Norris (1997) taler om. Fullick and Ratcliffe (1996) har til "Science, Ethics and Education Project" udgivet et materiale som rummer sådanne klassedialoger.

\section{Gruppearbejde.}

Mens klassedialogen har læreren som deltager og ofte som leder, så giver gruppearbejdet mulighed for at udvikle og udfolde en række evner i et fællesskab med ligeværdige partnere, hvor eleverne selv styrer og tager ansvar for deres læringssituation. Henrik Bang (2001) redegør for, hvordan gruppearbejde indgår som en af flere mulige arbejdsformer for tilegnelse af naturfaglig viden. For udvikling af et kritisk demokratisk beredskab er gruppearbejde et uundværligt pædagogisk redskab. Evner som at lytte til andre, at argumentere rationelt og at ræsonnere, at have selvtillid til at fremsætte sin egen mening, at accepter andres meninger og at anerkende deres bedre argumenter eller viden er fundamentale i en demokratisk proces. Diskussion af emner, der rummer tværfaglige socio-kulturelle og socio-politiske spørgsmål, er da også efterspurgt af danske gymnasieelever ifølge "Fysik i skolen - skolen i fysik" (2001 s.58). Et gruppearbejde skal imidlertid have et spørgsmål eller en problemformulering, som kan styre, strukturere og målrette diskussionen. Der må også foretages en evaluering af arbejdet i form af et referat, en dagbog, et elevoplæg, en rapport eller et andet "produkt", som også fremhævet af Jonathan Osborne (2000). I modsat fald kan gruppearbejdet blive en Pandoras æske af negative erfaringer for såvel lærere som elever.

\section{Konsensusprojekter.}

Kolstø (1997 og 2000) fremhæver projektarbejdsformen som den praksis, der bedst tilgodeser en dannelsesproces i et demokratisk perspektiv. Det er imidlertid ikke nogen entydigt praksis. Selv har han udviklet konsensusprojekter i skolemæssig sammenhæng. I projektforløbet stræbes der bevidst efter konsensus i løsningen af konkrete ofte lokale problemstillinger. Hovedvægten ligger på fremlæggelse og forsvar af data og konklusioner på baggrund af et kritisk arbejde i en sag, hvori der indgår et naturvidenskabeligt element. Imidlertid tilegnes den naturvidenskabelig viden ikke i den konkrete sammenhæng. Med henvisning til Layton (1991) og Jenkins (1994) tilstræber Kolstøe en transformation af allerede tilegnet viden med henblik på at kvalificere eleverne til anvendelse af denne viden som grundlag for meningsdannelse i de konkrete samfundsmæssige sammenhænge. Eleverne skal da agere som "eksperter" og kritisk vurdere hinandens konklusioner for til sidst at opnå konsensus og træffe en konkret beslutning. Kolstø (1997 s.81) mener, at det pædagogisk set ikke er tilstrækkelig at træffe en flertalsbeslutning ved afstemning, men at kravet om konsensus bevirker, at deltagerne er nødt til at forstå hinandens synspunkter. Kolstø sammenfatter det pædagogiske rationale bag konsensusprojekter således:

- Ikke at fortelle elevene at de skal være kritiske, men å praktisere det.

- Ikke å fortelle elevene at naturfaglig kunnskap er relevant for avveining mellom handlingsalternativer i dagligliv og demokrati, men å forsøke å legge til rette for at de kan erfare det.

- Ikke å fortelle elevene om kjennetegn ved naturviteskapelig kunnskap, men la de bli kjent med slike gjennom praktiske situasjoner.

- Ikke å fortelle elevene om naturvitenskapens natur, men å forsøksvis praksisere elementer fra den.

\section{Projektarbejde ved Roskilde Universitet.}

Igennem de sidste 25 år er der ved Roskilde Universitet udviklet en praksis for projektarbejde, der bygger på principperne problemorientering, deltagerstyring, tvcerfaglighed, eksemplaricitet og gruppearbejde. Disse principper, som Knud Illeris (1981) mere indgående har beskrevet, er udviklet i en akademisk uddannelsesmæssig sammenhæng. De har imidlertid igennem de sidste år vundet indpas i mange andre uddannelses- og skoleformer. Det er derfor relevant at inddrage dem netop i denne sammenhæng. 
Problemorientering betyder, at udgangspunktet for projektarbejdet ikke er et fag eller et fagligt emne, men et problem eller spørgsmål ofte af aktuel karakter. Problemorienteringen åbner for mange løsningsmuligheder og læreprocessen er åben og uafsluttet. Formuleringen af problemet kommer til at spille en væsentlig rolle som det redskab, der giver kriterier for både valg og afgrænsning af indhold. Dette er en væsentlig forskel i forhold til et emnearbejde, hvor der på forhånd foreligger en bestemt læringsopgave, som kan afsluttes, og hvor vejlederen behersker emnet og opfatter sig selv som lærer, mens de øvrige deltagerne opfatter sig selv som elever.

Deltagerstyring indebærer en intention om, at undervisningens rammer udfyldes af deltagerne selv, der således har indflydelse på og ansvar for udviklingen af egne kvalifikationer. Vejlederen, læreren, er deltager på lige fod med de øvrige deltagere, men med særlige opgaver og et særligt ansvar såvel indadtil overfor gruppen og dens arbejde som udadtil over for uddannelsens mål og kvalitet. Deltagerstyring indebærer således en rollefordeling, der sikrer medindflydelse og ansvar, som nødvendige forudsætninger for udvikling af selvstændighed og stillingtagen.

Tvcerfaglighed bliver i reglen en konsekvens af problemorienteringen, idet flere fag kommer til at indgå $\mathrm{i}$ et kvalificeret arbejde med problemet. Der er imidlertid ikke tale om en instrumentel anvendelse af faglige elementer, som ikke medfører nogen videre faglige kvalifikationer. Selvom der er tale om en nedbrydning af traditionelle faglige grænser, er der ifølge Paulsen (1997) stadig et krav om fordybelse i og anvendelse af naturfaglige teorier i den konkrete sammenhæng, som problemformuleringen definerer.

Det eksemplariske princip, som oprindelig er formuleret af Klafki, er for den fagcentrerede naturfaglige undervisning især behandlet af Wagenschein (1956), men i et kritisk demokratisk dannelsesperspektiv er Oscar Negt (1971) mere relevant. Princippet indebærer, at arbejdet med et problem er eksemplarisk, hvis deltagerne opnår kvalifikationer, som er almene for et arbejdsområde, et problemfelt $\mathrm{i}$ et fag eller i samfundet. Det vil altså sige, at det valgte problem på en gang skal være subjektivt interessante for eleverne og have objektiv relevans i relation til uddannelsens mål.

Gruppearbejde er allerede beskrevet ovenfor. Derfor skal der her blot fremhæves, at et gruppearbejde af længere varighed i forbindelse med projekter, hvor der er krav om et produkt og formidling, er af gensidig forpligtende art for deltagerne og derfor også i særlig grad identitets- og personlighedsdannende.

\section{Rollespil og drama}

Et rollespil indeholde i reglen et scenario. Selvom et sådant scenario ikke nødvendigvis afspejler en virkelig situation, så rummer den gerne en aktuel problematik, i hvilken eleverne har en mulighed for at agere i realistiske situationer. Eleverne bliver så at sige frisat ved at blive løst fra skolesituationen og påtage sig en rolle. Man skal dog være opmærksom på, som nævnt af Paulsen (1987), at præmisserne for beslutningerne og dermed også det mulige udfaldsrum for beslutninger sættes af instruktøren. En dybtgående behandling af rollespil og drama i et emancipatorisk og kritisk demokratisk dannelsesperspektiv er givet af Marianne Ødegaard (2001), se også hendes kapitel i denne bog. Også hun henviser til, at naturvidenskabelig viden først må transformeres ind i en konkret situation for at kunne anvendes i demokratiske beslutningsprocesser.

\section{LARERKOM PETENCER}

Jeg anser den pædagogiske diskurs blandt naturfagslærerne og ikke mindst blandt læreruddannere for at være de væsentligste faktorer i en ændringsproces af den konventionelle naturfaglige undervisning eller, som nogle foreslår, til etableringen af et nyt naturfag med et alment og kritisk demokratisk dannelsesperspektiv. Nogle af årsagerne til, at dette perspektiv kun i ringe grad tilgodeses, er blevet diskuteret ovenfor. Spørger man imidlertid lærerne, så er de væsentlige årsager 
den traditionelle lærerrolle, en traditionel fagopfattelse, lærebøgerne og manglende tid på grund af læreplanens krav, se også "Fysik i skolen - skolen i fysik" (2001 s.84 og s.218) og Newton et al. (1999). Det følgende er inspireret af Putnam og Borko (1997) som har elaboreret Shulmans begreb pedagogical content knowledge, Det er et forsøg på at angive, hvilke kompetencer læreren må udvikle for at undervise i naturfag for et kritisk demokratisk beredskab. I de nedenfor opstillede lærerkompetencer har jeg valgt ordet "fantasi" i stedet for begreber som færdighed og kunnen. Det er for at understrege, at der her er tale om kompetencer, som ikke bare kan erhverves og så anvendes. Det er et forældet og instrumentelt syn lærergerningen, at det er muligt, at uddanne lærere, som en gang for alle har lært at være lærere. Denne opfattelse hører sammen med den såkaldte "rutinerede lærer" til i et industrisamfund. For læreren i dag er hver undervisningssituation en ny situation. Lærere må derfor uddannes til sammen med deres elever at udvikle egen undervisning.

\section{Faglig fantasi:}

Læreren må kunne frigøre sine faglige refleksioner fra de traditionelle faglige strukturer og sammenhænge, som præger lærebøgerne, og som f.eks. for fysikkens vedkommende i det væsentlige er udviklede i 1700- og 1800 tallet. Undervisningens indhold kan ikke vælges udfra, hvilke faglige begreber og teorier i en konventionel faglig diskurs, der potentielt vil passe til elevernes forudsætninger. Det faglige niveau er ikke en størrelse, som ifølge Paulsen (1998) - reelt eller illusorisk - er klart defineret ved et pensum. Tværtimod, når konteksten bestemmer det begrebslige indhold, så må læreren omarbejde og tilpasse den faglige viden (i princippet hvilken som helst faglig viden) til konteksten og til elevernes forudsætninger. Denne kontekstualisering af viden sker ofte i komplicerede, tværfaglige og autentiske sammenhænge. Læreren må have evnen til narrativt og ved relevante metaforer og analogier at forklare og fremstille naturvidenskabelig viden løsrevet fra de traditionelle naturvidenskabelige sammenhænge. Læreren må være åben og ikke have berøringsangst overfor andre fag og turde vælge og vurdere deres potentielle bidrag, således at relevant viden kan blive inddraget på tværs af fagene. Lærerens faglige refleksioner må i den konkrete situation også omfatte fagenes epistemologiske, kulturelle og historiske sammenhænge.

\section{Fag-"sociologisk fantasi" (udtrykket er her "lånt" fra Oscar Negt 1977):}

Læreren må kunne reflektere over sociologiske og politiske elementer i den aktuelle kontekst og over muligheden for at inddrage dem eksemplarisk og erkende, at vurderinger og beslutninger om anvendelse af naturvidenskabelig viden sjældent kan træffes på baggrund af rent objektive faglige overvejelser. Udover etiske og værdimæssige betragtninger kan refleksionerne også omfatte samfundsmæssige forhold såvel som kommercielle interesser, økonomiske vilkår, prestige, anseelse og meget andet. Douglas Allchin (1999, p.10) stiller en række spørgsmål om hvem og hvad, der har magten og styrer produktion og anvendelse af naturvidenskabelig viden, som i konkrete situationer kan tages op i undervisningen, som f.eks.:

- Who are the stakeholders? What are their interests? Are they involved in the decisionmaking?

- What are the foreseeable consequences (possible remote or hidden)? What are the alternatives? Is the worst case scenario acceptable?

- What are the benefits? What are the costs?

- Who benefits? Who risks ore pays the costs?

- What would be the outcome if everyone acted this way?

\section{Faglig-pædagogisk fantasi:}

Det fremgår af ovenstående forslag til praksis, at den autentiske situation er det ideelle udgangspunkt for en socio-politisk diskurs. Det foregår imidlertid i en pædagogisk sammenhæng og må derfor ske under hensyntagen til elevernes kognitive og affektive forudsætninger. Læreren må derfor have et godt kendskab til børn og unges udvikling og inddrage det i sine pædagogiske refleksioner. Således kommer elevernes forhåndsopfattelse af verden omkring dem, de såkaldte hverdagsbegreber, til at spille en væsentlig rolle for, hvordan eleverne begriber ny viden og nye for- 
klaringer. En omfattende litteratur er til rådighed om elevernes forforståelse og tankemønstre. Det banebrydende arbejde er refereret af Driver, Guesne and Tiberghien (1985) og en meget grundig fremstilling er givet af Björn Andersson (2001) i: Elevans tänkande och skolans naturvetenskap. Forskningsresultat som ger nya idéer.

\section{Praktisk pædagogisk fantasi:}

Læreren skal kunne skabe en et trygt klassemiljø og have evne til at variere undervisningen i overensstemmelse med de behov, eleverne, har og med arbejdet karakter. Hun skal kunne organisere og lede en gruppediskussion, hvori hun selv er ligeværdig deltager og kunne etablere et gruppearbejde, forstå at sammensætte grupper og løse konflikter i grupperne. Hun skal kunne vejlede i et projektarbejde og kunne hjælpe deltagerne igennem de forskellige faser i arbejdet og de problemer og frustrationer, som ufravigelig opstår. Det kræver en høj grad af selvtillid og personlig myndighed at frigøre sig fra en traditionel lærerrolle og blive deltager i en socio-politisk diskurs. Læreren er den naturfaglig ekspert men som partner og ikke som dominerende magtfaktor. I den traditionelle lærerrolle er selvstændighed noget, læreren kan give eleven. I en socio-politisk diskurs er det elevens selvfølgelige ret at have selvstændige meninger og give udtryk for dem. Ganske særlige og specielle pædagogiske evner kræves der til at etablere et rollespil.

\section{Curricular fantasi:}

Læreren må have systemviden, dvs. indsigt i skolen som et system i samfundet med love og bestemmelser for selvstændigt at kunne fortolke læreplanerne uafhængig af tradition, lærebøger eller andre tvivlsomme autoritative kilder. De skandinaviske læreplaner er rammeplaner, som skal fortolkes. Planerne indeholder bl.a. de ofte konfliktfyldte mål og indholdselementer, som er diskuteret ovenfor. Derfor - og måske netop derfor - må læreren være i besiddelse af en professionel selvtillid til at fortolke og selvstændigt udvikle sin undervisning.

Sådanne kompetencer kan ikke erhverves men udvikles løbende i en praksis, et lærerfællesskab, hvor der kan samarbejdes om undervisningen, og hvor der er en diskurs om skolens pædagogik og kultur også på det naturfaglige område. Dette syn på lærerjobbet er helt afgørende, når det drejer sig om undervisning i naturfag i et kritisk demokratisk dannelsesperspektiv. Det må begynde på læreruddannelsesinstitutionerne.

\section{LITTERATUR}

Allchin, D. (1999). Values in Science: An Educational Perspective. Science \& Education, 8, 1-12. ALF (2001). At Loere Fysik - Et studium i gymnasieelevers loereprocesser i fysik. Uddannelsesstyrelsens temahæfteserie nr.19 - 2001. Undervisningsministeriet. Undervisningsministeriets forlag. Strandgade 100D, 1401 København K.

Andersson, B.(2001). Elevans tänkande och skolans naturvetenskap. Forskningsresultat som ger nya idéer. Skoleverket. Liber Distribution. Publikationstjänst. Stockholm.

AQA (2001/2). Science for Public Understanding. Specifications. Specimen units and mark schemes. Teacher's guide. Assessment and Qualifications Alliance. Advanced Subsidiary. General Certificate of Education. Manchester.

Bang, H. (2001). Det længerevarende gruppearbejde I: At Loere Fysik - Et studium i gymnasieelevers loereprocesser $i$ fysik. Uddannelsesstyrelsens temahæfteserie nr.19 - 2001. Undervisningsministeriet.

Bang, J. (1998). Læring og Kompetence. Psyke \& Logos, 19, 415-434.

Bang, J. (2001). Den lærerstyrede klassedialog. I: At Loere Fysik - Et studium i gymnasieelevers loereprocesser $i$ fysik. Uddannelsesstyrelsens temahæfteserie nr.19 - 2001. Undervisningsministeriet.

Black, P., Atkin, J.M. (Eds.)(1996). Changing the Subject. Routledge and OECD. 
Brown, J.S., Collins, A., Duguid, P. (1989). Situated Cognition and the Culture of Learning. Educational Researcher. 18(1), 32-42.

Dewey, J. (1966). Democracy and Education. The Free Press. Collier-Macmillan Limited.

Dolin, J. (2000). Veerdier og undervisning $i$ fysik. Uddannelsesstyrelsen. Temahæfteserie nr.17.

Driver, R., Guesne, E. og Tiberghien, A. (1985). Children's Idea in Science. Open University Press, UK.

Duschl, R.A., Ellenbogen, K. (2001). Understanding Dialogic Argumentation Among Middle School Science Students. I: Psillos, D. et.al.(Eds.). Science Education Research in the Knowledge Based Society. Proceedings of the Third International Conference of the European Science Education Research Association (ESERA). Thessaloniki, Greece 2001.

Eger, M. (1989). The interest' of science and the problem of education. Synthese 81, 81-106.

Emmeche, K. (1999). Naturvidenskab - sand almen dannelse. Undervisningsministeriet tidsskrift Uddannelse. Nr.5.

Fensham, P.(2000). Providing suitable content in the "science for all" curriculum" I: R. Millar, J. Leach og J. Osborne (red). Improving science education. The contribution of research. Open University Press.

Fullick, P. \& Ratcliffe, M. (Red.)(1996). Teaching Ethical Aspects of Science. Science, Ethics and Education Project. The Bassett Press. Southampton.

Fysik i skolen - skolen i fysik. Evaluering af fysik i det almene gymnasium. 2001. Danmarks Evalueringsinstitut.

Harlen, W. (1999). The assessment of scientific literacy in the OECD/PISA project. I: H. Behrendt, H. Dahnke, R. Duit, W. Gäber, M. Komorek \& A. Kross (Red.) (2001). Research in Science Education - Past, Present, and Future. Kluwer Academic Publishers.

Hennessy, S. (1993). Situated Cognition and Cognitive Apprenticeship: Implications for Classroom Learning. Studies in Science Education, 22, 1-41.

Illeris, K. (1981). Modkvalificeringens paedagogik. Probelmorientering, deltagerstyring og eksemplarisk loering. Unge Pædagoger. København.

Jenkins, E.W. (1994). Public understanding of science and science education for action. Journal of Cirriculum Studies 26 (6), 601-611.

Jenkins, E.W. (1997). Scientific and Technological Literacy for Citizenship: What can we learn from research and other evidence. I: S. Sjøberg \& E. Kallerud (red.). Science, Technology and Citizenship. Rapport 7/97. Norsk Institutt for studier av forskning og utdanning.

Jenkins, E.W. (1999). Practical work in School Science: Some questions to be answered. I: J. L. Leach \& A. C. Paulsen (red.). Practical Work in Science Education. Recent Research Studies Kluwer academic publishers and Roskilde University Press.

Jenkins, E.W. (2000). "Science for all": time for a paradigme shift? I: R. Millar, J. Leach \& J. Osborne (red.). Improving science education. The contribution of research. Open University Press.

Jensen, B.B. \& Schnack, K. (1994). Action and Action Competence as Key Concepts in Critical Pedagogy. Didaktiske Studier bd.12. Danmarks Lærerhøjskole.

Jørgensen, E. (1999). Jens Lyn møder risikosamfundet. Fysik\&kemigruppen 99.3. Danmarks Lærerhøjskole. Institut for Matematik, Fysik, Kemi og Informatik. Publikation nr.38.

Karplus, R. \& Thiers, H.D. (1966). Toward Scientific Literacy. Education Age. Minnesota Mining and Manufacturing Company.

Klafki, W. (2001). Dannelsesteori og didaktik - nye studier. Klim. Aarhus.

Knain, E. (1999). Naturfagets tause stemme. Diskursanalyse av loerebøker for Natur- og miljøfag $i$ et allmenndannelsesperspektiv. Det matematisk-naturvitenskapelige fakultet. Universitetet i Oslo.

Kolstø, S.D. (1997). Naturvitenskap og demokrati: Hva kan skolefaget bidra med? I: E. Kallerud \& S. Sjøberg (red.). Vitenskap, teknologi og allmenndannelse. NIFU, Norsk Institutt for studiet av Forskning og Utdanning.

Kolstø, S.D. (2000). Consensus projects: teaching science for citizenship. International Journal of Science Education. 22, 645-664. 
Kolstø, S.D. (2001). Pupils' argumentation: knowledge, values and decisions. I: Psillos, D. et.al.(Eds.). Science Education Research in the Knowledge Based Society. Proceedings of the Third International Conference of the European Science Education Research Association (ESERA). Thessaloniki, Greece 2001.

KUF (1996) Laereplanverket for den 10-årige grunnskolen. Oslo: Det kongelige kirke-, utdanningsog forskningsdepartement.

Lave, Jean (1988). Formidling eller praktisk forståelse. Udkast 2, 1988.

Lave, J., Wenger, E. (1991). Situated learning : legitimate peripheral participation. Cambridge University Press.

Layton, D. (1991). Science Education and Praxis: the relationship of school science to practical action. Studies in Science Education, 19, 43-79.

Layton, D., Jenkins, E., Macgill, S., \& Davey, A. (1993). Inarticulate Science. Perspecticves on the Public Understanding of Science and Some Implications for Science Education. Studies in Education Ltd, Nafferton.

Lemke, J., L. (1990). Talking Science: Language, Learning, and Values. Ablex Publishing Corporation. Norwood, New Jersey.

Millar, R., Wynne, B.(1988). Public understanding of science: from content to processes. International Journal of Science Education,10 (4), 388-398.

Millar, R (1996). Towards a science curriculum for public understanding. School Science Review 77, 7-18.

Millar, R., Osborne, J. (red.) (1998). Beyond 2000. Science Education for the future. King's College. School of Education. London. På internet: http://www.kcl.ac.uk/depsta/education/be2000/

Negt, O. (1977). Sociologisk fantasi og eksemplarisk indloering. Roskilde Universitetsforlag.

Newton, P., Driver, R., Osborne, J. (1999). The place of argumentation in the pedagogy of school science. International Journal of Science Education, 21 (5), 553-576

Nielsen, B. (1973). Praksis og kritik. Christian Ejlers forlag.

Nielsen, H., Thomsen, P. (1990). "History ens Philosophy of Science in the Danish Curriculum. International Journal of Science Education. 12(4), 308-316.

Niss, M. og Jensen, J.H. (1984). For matematik og fysik i fremtidens gymnasium. I: Jensen, J.H., , Niss, M. m.fl.: Nogle artikler om matematik, fysik og almendannelse. IMFUFA, Tekst nr.84. Roskilde Universitetscenter.

Norris, S.P. (1997). Intellectual Independence for Non-scientists and other Content-Transcendent Goals. Science Education 81, 239-258.

Osborne, J. (2000). Science for citizenship. I: M. Monk \& J. Osborne: Good practice in science teaching. What research has to say. Open University Press.

Osborne, J., Simon, S., Erduran, S. \& Monk, M. (2001). Enhancing the Quality of Argument in School Science. I: Psillos, D. et.al.(Red.). Science Education Research in the Knowledge Based Society. Proceedings of the Third International Conference of the European Science Education Research Association (ESERA). Thessaloniki, Greece 2001.

Ott, A. (2000). Att lära för skolan eller för livet? Sociokulturel och naturvetenskaplig diskurs i växelverkan. Nordisk pedadogik, 20 (2), 90-106.

Paulsen, A.C. (1980). The legitimacy of physics teaching. A contribution to "Physics for all future citizens. In: Ganiel, U.(ed.)(1980). Physics Teaching. Girep Conference 1979, Rehovot, Israel. Balaban. International Science Service. Jerusalem.

Paulsen, A.C. (1987). Science, Technology and Democratization. In: Advances in Science and Technology Education. The ICASE 1987 Yearbook. ICASE.

Paulsen, A.C. (1997). Andre faglige kompetencer. Undervisningsministeriet tidsskrift Uddannelse. Nr.8, 1997.

Phenix, Ph., H. (1962). The disciplines as Curriculum Content. I: A.H. Passow (red.). Curriculum Crossroads. New York, Teacher College Press, Columbia University.

Phenix, Ph., H. (1964). Realms of meaning : a philosophy of the curriculum for general education. New York, McGraw-Hill. 
Putnam, R.T., Borko, H.(1997). Teacher Learning: Implications of New Views of cognition. I: International handbook of Teachers and teaching. Volume II.Kluwer.

Reisby, K.(1994). Har naturfagsundervisning betydning for demokratisk dannelse. I: K. Schnack (red.) Fagdidaktik og dannelse - $i$ et demokratisk perspektiv. Didaktisk studier. Bind 10. Danmarks Lærerhøjskole.

Schnack, K (1994). Dannelse som et pædagogisk perspektiv. I: K. Schnack (red.). Fagdidaktik og dannelse - $i$ et demokratisk perspektiv. Didaktisk studier. Bind 10. Danmarks Lærerhøjskole.

Sfard, A. (1998). On Two Metaphors for Learning and the Dangers of Choosing Just One. Educational Researcher, 27 (2), 4-13.

Siegel, H. (1989). The rationality of science. Synthese, 80, 9-41.

Sjøberg, S. (1994). Naturvetenskap, demokrati og dannelse. I: K. Schnack (red.). Fagdidaktik og dannelse - $i$ et demokratisk perspektiv. Didaktiske studier. Bind 10. Danmarks Lærerhøjskole.

Sjøberg, S. (1998). Naturfag som allmenndannelse - en kritisk fagdidaktik. Ad Notam Gyldendal.

Sjøberg, S. (1997). Scientific Literacy and School Science. Arguments and second thoughts. In: Sjøberg, S., Kallerud, E. (1997). Science, Technology and Citizenship. Rapport 7/97. Norsk Institutt for studier av forskning og utdanning.

Sjøberg, S., Kallerud, E. (1997). Science, Technology and Citizenship. Rapport 7/97. Norsk Institutt for studier av forskning og utdanning.

Undervisningsministeriet (1994). Formål og centrale foerdighedsområder. Folkeskolens fag.

Ziman, J. (1991). Public understanding of science. Science, Technology and Human Values, 16 (1), 99-105.

Wynne, B. (1991). Knowledge in context. Science, Tachnology and Human Values 16 (1), 111121.

Ødegaard, M. (2001). The Drama of Science Education. How public understanding of biotechnology and drama as learning activity may enhance a critical and inclusive science education. Faculty of Mathematics and Natural Sciences. University of Oslo. 